\title{
HARWELL RADIOCARBON MEASUREMENTS III
}

\section{R L OTLET and A J WALKER}

\author{
Nuclear Physics Division, Atomic Energy Research Establishment, \\ Harwell, Oxfordshire, England
}

The dates in this list follow on, approximately chronologically, from Harwell II (R, 1977, v 19, p 400-423) and refer principally to measurements carried out in the period 1975-6. Laboratory techniques have remained essentially unchanged from earlier reports but a full description of the setting-up philosophy and operating procedure of the liquid scintillation counting systems has now been published separately (Otlet and Warchal, 1977).

As before, calculations are based on the Libby half-life of $5568 \mathrm{yr}$ and 0.95 times the NBS oxalic acid standard as 'modern', (both values treated as constants) and AD 1950 as the reference year. All results are corrected for fractionation according to the given $\delta^{13} \mathrm{C}$ (wrt PDB) values.

The policy of giving as $\pm 1 \sigma$ standard error an estimate of the full replicate sample reproducibility of the laboratory process and not just counting statistics has been continued. Publication of the estimation procedure given at the 9th International Conference on Radiocarbon Dating (Otlet, 1976) is expected shortly.

\section{ACKNOWLEDGMENTS}

We wish to acknowledge the work of B Slade, D G Humphreys, G A Bradburn, and E F Westall in the laboratory measurements and the financial support and co-operation from staff of the Dept of Environment (Ancient Monuments Laboratory) through which a number of samples (those additionally referenced with AML numbers) were submitted. Our thanks are also due to the individual submitters for their comments and permission to publish their results in this list.

\section{ARCHAEOLOGIC SAMPLES}

\section{A. British Isles}

\section{Roxton series}

Samples from Ring Ditches at Roxton, Bedfordshire, England $\left(52^{\circ}\right.$ $9^{\prime} 50^{\prime \prime} \mathrm{N}, 0^{\circ} 19^{\prime} \mathrm{W}$, NGR: TL156536). Coll by P J Woodward \& A Taylor; subm Jan 1975 by P J Woodward.

\section{HAR-711. ROX73D/Q2/X/16}

$$
\begin{array}{r}
1420 \pm 70 \\
\delta^{13} C=-26.3 \% \text { o }
\end{array}
$$

Charcoal. Comment (PJW): no other evidence of occupation date available but result agrees with stratigraphy of Ring Ditch siltings. Hearth from which sample was taken was cut into a silt layer (resulting from ploughing) containing 3rd century AD Roman pottery. 
HAR-997. ROX74B/Q2/338

$$
3620 \pm 80
$$

$\delta^{13} \mathrm{C}=-25.2 \%$

Charcoal, AML 744056, from central burial in Ring Ditch B. Cremation in 2 Collared Urns in small pit. Comment (PJW): result is satisfactory and agrees well with Bronze age Collared Urns of this type.

HAR-998. ROX74B/Q1/V/23

$$
\begin{array}{r}
\mathbf{7 7 0 0} \pm \mathbf{1 7 0} \\
\delta^{13} \mathrm{C}=-25.5 \% 0
\end{array}
$$

Charcoal, AML 744056, found sealed in Ring Ditch B which had been deliberately in-filled soon after construction. Comments: small sample accounts for larger than usual error term (PJW): date older than expected. Sample was sealed in primary fill of Ring Ditch which surrounded central burial, dated as HAR-997 qv, and was, therefore, expected to be nearer to, and slightly later than, HAR-997.

\section{HAR-999. ROX74/CQ2/330}

$$
\begin{array}{r}
\mathbf{3 8 0 0} \pm \mathbf{1 3 0} \\
\delta^{13} \mathrm{C}=-25.3 \% 0
\end{array}
$$

Charcoal, AML 744056, assoc with robbed primary burial urn of Early-Mid Bronze age date. Comment (PJW): agrees with probable date of burial urn and HAR-997 qv.

\section{HAR-1000. ROX74/CQ2/339}

$$
\begin{array}{r}
\mathbf{3 6 0 0} \pm \mathbf{8 0} \\
\delta^{1.3} C=-25.0 \%
\end{array}
$$

Charcoal, AML 744056, sampled for possible assoc with either robbed primary or with secondary burial. Comment (PJW): date is satisfactory since intermediate date between HAR-999 and -1001 reinforces hypothesis that this charcoal is not linked entirely with either primary or secondary burials.

\section{HAR-1001. ROX74C/K3/X1/21}

$$
\begin{array}{r}
\mathbf{3 1 3 0} \pm \mathbf{6 0} \\
\delta^{13} C=-25.5 \% 0
\end{array}
$$

Charcoal, AML 744056, found with mass of cremated bones and 2 bone toggles, presumably representing bagged burial. Comment (PJW): this secondary burial was in discrete concentration in central pit below HAR-1000 and -999, which gave earlier dates. Date, some $600 \mathrm{yr}$ later, is satisfactory in that it shows date reversal in pit.

\section{HAR-1002. ROX74C/Q3/X1/11}

$$
\begin{array}{r}
\mathbf{3 6 2 0} \pm \mathbf{~ 8 0} \\
\delta^{13} C=-24.6 \%
\end{array}
$$

Charcoal, AML 744056, from in situ fire in larger pit. Comment (PJW): as with HAR-1000, intermediate date between robbed primary burial, HAR-999, and secondary burial, HAR-1001, is satisfactory. Sample came from cleaned-out hearth assoc with secondary burial but fill is probably mixture of carbon of secondary and primary dates.

HAR-1003. ROX74C/QI/VI/II9/109

$$
\begin{array}{r}
\mathbf{3 2 0 0} \pm \mathbf{5 0} \\
\delta^{13} C=-26.0 \%
\end{array}
$$

Charcoal, AML 744056, with cremation in part of inverted urn near bottom of Ring Ditch C, cut into primary fill. Comment (PJW): result 
ties in well with others for Ring Ditches B and C and also with nature of Middle Bronze age urn in which charcoal was contained.

HAR-1004. ROX74C/Q2/V/II

$$
\begin{array}{r}
1640 \pm \mathbf{8 0} \\
\delta^{13} C=-26.0 \%
\end{array}
$$

Charcoal, AML 744056, from hearth cut into top silting of Ring Ditch C. Comment (PJW): exactly parallel hearth was found on Ring Ditch $\mathrm{D}$ and dated to $1420 \pm 70$, HAR-711. From site evidence, 2 dates were expected to be very nearly the same or, at any rate, closer than 2 results suggest.

\section{Forcegarth series}

Samples from series of excavations at Forcegarth Pasture, Forest in Teesdale, Co Durham, England (Fairless \& Coggins, 1974; 1978). Samples subm by K J Fairless, Dir Excavations, Middleton St George Coll Educ.

\section{HAR-864. FORCEGAR}

$$
\begin{array}{r}
1810 \pm 70 \\
\delta^{13} C=-26.9 \%
\end{array}
$$

Charcoal fragments from floor level of $\mathrm{E}$ room of central house at Forcegarth Pasture North (54 $39^{\prime} 5^{\prime \prime} \mathrm{N}, 2^{\circ} 11^{\prime} 40^{\prime \prime} \mathrm{W}$, NGR: NY 875285). Coll Aug 1974 by D Coggins; subm Nov 1974. Comment (KJF): result is not inconsistent with coarse Iron age pottery found at same level outside entrance of $\mathrm{E}$ room.

\section{HAR-1447. NY875283}

$$
\begin{array}{r}
1740 \pm 90 \\
\delta^{13} C=-26.0 \%
\end{array}
$$

Charcoal from foundation trench of pre-stone period house at Forcegarth Pasture South (54 $38^{\prime} 55^{\prime \prime} \mathrm{N}, 2^{\circ} 11^{\prime} 40^{\prime \prime} \mathrm{W}$, NGR: NY875283). Coll Aug 1975 and subm Dec 1975. Comment (KJF): result is not inconsistent with Roman period pottery recovered from succeeding stone phase of house.

\section{Somerset Levels series}

Dates reported below refer to samples taken during 1974 and 1975 . A short note introducing project with earlier results is given in Harwell II (R, 1977, v 19, p 415-416). Detailed information on archaeology of area and dendrochronol and palaeobot studies under way is reported in Somerset Levels Papers 1 to 5 (Coles et al, 1975; 1976; 1977; Coles, 1978; 1979). Unless otherwise stated, all samples coll and subm by J M Coles, Dept Archaeol, Cambridge.

\section{HAR-943. SLP7411}

$$
\begin{array}{r}
\mathbf{2 9 8 0} \pm \mathbf{7 0} \\
\delta^{13} \mathrm{C}=-29.8 \% \text { o }
\end{array}
$$

Wood, AML 744091, from brushwood platform beneath $0.5 \mathrm{~m}$ peat at Meare Lake, Shapwick (51 $9^{\prime} 30^{\prime \prime}$ N, $3^{\circ} 47^{\prime} 30^{\prime \prime}$ W, NGR: ST444406). Platform overlain by wood structure of heavy upper timbers (HAR-683, $3290 \pm 70, \mathrm{R}, 1977, \mathrm{v} 19$, p 416). Comment (JMC): result suggests that heavy planking used for upper layer was already old when put into use. Date also helps relate Meare Lake structure to other prehistoric material in area (Coles, 1978, p 32, 41). 
HAR-944. SLP7412

Wood, AML 744092, from timbers of dismantled structure at edge of fen, beneath 1 to $2 \mathrm{~m}$ peat originally but only $0.2 \mathrm{~m}$ in 1974 (Coles $e t$ al, $1975)$ at Withy Bed Copse, Shapwick ( $51^{\circ} 8^{\prime} 50^{\prime \prime} \mathrm{N}, 2^{\circ} 48^{\prime} 20^{\prime \prime} \mathrm{W}$, NGR: ST435394). Comment (JMC): date provides useful reference for relating this prehistoric material to known wooden structure to $\mathrm{N}$ and $\mathrm{E}$ of this site.

\section{HAR-945. SLP7413 (Tinney's $1.7: 2.6$ )}

$$
\begin{array}{r}
\mathbf{3 0 4 0} \pm \mathbf{7 0} \\
\delta^{1 s} C=-29.3 \% \text { o }
\end{array}
$$

Wood, AML 744093, from brushwood of wooden trackway beneath $\mathrm{lm}$ peat at Tinney's Ground, Shapwick $\left(51^{\circ} 8^{\prime} 15^{\prime \prime} \mathrm{N}, 2^{\circ} 45^{\prime} 30^{\prime \prime} \mathrm{W}\right.$, NGR: ST469382). Comment (JMC): confirms projected interrupted wooden trackway (HAR-681, $3040 \pm 70: \mathrm{R}, 1977$, v 19, p 416 and HAR948, $3020 \pm 70$ ). Assists dendrochronol studies of area (Coles, 1978, p 73).

HAR-946. SLP7414 (Tinney's 1.6:2.3)

$$
\begin{array}{r}
2950 \pm 80 \\
\delta^{13} C=-30.0 \% 0
\end{array}
$$

Wood, AML 744094, from brushwood of wooden trackway beneath

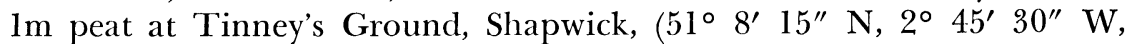
NGR: ST469382). Comment (JMC): result indicates general contemporaneity of trackways close to one another, near suggested later Bronze age settlement. Different trackway from HAR-945 and -947 (qv).

\section{HAR-947. SLP7415 (Tinney's $1.3: 2.1$ )}

$$
\begin{array}{r}
\mathbf{2 9 6 0} \pm \mathbf{7 0} \\
\delta^{13} C=-29.4 \% \text { \% }
\end{array}
$$

Wood, AML 744095, from brushwood of wooden trackway beneath $1 \mathrm{~m}$ peat at Tinney's Ground $\left(51^{\circ} 8^{\prime} 15^{\prime \prime} \mathrm{N}, 2^{\circ} 43^{\prime} 45^{\prime \prime} \mathrm{W}\right.$, NGR: ST 489382). Comment (JMC): as HAR-946.

HAR-948. SLP7416 (Tinney's 9.3:10.3)

$$
\begin{array}{r}
\mathbf{3 0 2 0} \pm \mathbf{7 0} \\
\delta^{13} C=-28.1 \% \text { \% }
\end{array}
$$

Wood from brushwood of wooden trackway beneath $1 \mathrm{~m}$ peat at Tinney's Ground, Shapwick (51 $51^{\circ} 8^{\prime} 15^{\prime \prime} \mathrm{N}, 2^{\circ} 43^{\prime} 45^{\prime \prime} \mathrm{W}$, NGR: ST 470382). Comment (JMC): as HAR-945.

\section{HAR-1159. SLP751 (SK W 26)}

$$
\begin{array}{r}
\mathbf{3 3 3 0} \pm \mathbf{7 0} \\
\delta^{13} \mathrm{C}=-28.1 \% \text { 。 }
\end{array}
$$

Peat taken adjacent to Bronze age wooden pitchfork, sealed beneath original $0.5 \mathrm{~m}$ peat at Skinner's Wood, Shapwick $\left(51^{\circ} 9^{\prime} 40^{\prime \prime} \mathrm{N}, 2^{\circ} 50^{\prime} \mathrm{W}\right.$, NGR: ST416404). Comment (JMC): dates unique implement. Peat sequence here follows standard stratigraphy (Coles, 1978, p 114).

\section{HAR-1219. SLP755 (CV 2 B42)}

$$
\begin{array}{r}
4460 \pm 90 \\
\delta^{13} C=-27.8 \%
\end{array}
$$

Wood from brushwood track (one of joined pair) running $\mathrm{N}$ from Polden Hills, at Garvin's Track B, Sharpham $\left(51^{\circ} 8^{\prime} 25^{\prime \prime} \mathrm{N}, 2^{\circ} 46^{\prime} 50^{\prime \prime} \mathrm{W}\right.$, NGR: ST453385). Comment (JMC): result must be compared with HAR- 
$682(4380 \pm 70: \mathrm{R}, 1977$, v 19, p 416) and HAR-1222. HAR-682 represents a single joined track S of HAR-1219 and -1222. All dates agree internally and also with peat stratigraphy (Coles, 1978, p 79).

HAR-1220. SLP752

$$
4160 \pm 100
$$

$$
\delta^{13} \mathrm{C}=-28.8 \% \text { o }
$$

Wood from wooden track made of multiple hurdles at Walton track, Walton Heath, Meare (51 ${ }^{\circ} 8^{\prime} 50^{\prime \prime} \mathrm{N}, 2^{\circ} 46^{\prime} 45^{\prime \prime} \mathrm{W}$, NGR: ST454393). Comment (JMC): date agrees with peat stratigraphy and with absolute level OD. Oldest known wooden hurdles surviving and must relate to reports of 'hurdling' with Neolithic barrows (Coles et al, 1977).

\section{HAR-1221. SLP753}

$$
\begin{array}{r}
\mathbf{3 0 5 0} \pm \mathbf{7 0} \\
\delta^{13} C=-29.0 \%
\end{array}
$$

Wood from sparse remnants of wood track running towards Glastonbury Stileway, Meare (51 $9^{\prime} 35^{\prime \prime}$ N, $2^{\circ} 45^{\prime} 50^{\prime \prime}$ W, NGR: ST465408). Comment (JMC): dates structure in archaeol new area; agrees with peat stratigraphy. Many prehistoric structures of late 2nd millennium are now known (Coles, 1978, p 92).

\section{HAR-1222. SLP754. (GV2 A46)}

$$
\begin{array}{r}
\mathbf{4 2 8 0} \pm \mathbf{7 0} \\
\delta^{13} C=-28.5 \%
\end{array}
$$

Wood from brushwood track, running $\mathrm{N}$ from Polden Hills at Garvin's Track 4, Sharpham $\left(51^{\circ} 8^{\prime} 25^{\prime \prime} \mathrm{N}, 2^{\circ} 46^{\prime} 50^{\prime \prime} \mathrm{W}\right.$, NGR: ST 453385). Comment (JMC): as HAR-1219.

\section{HAR-1383. SLP756}

$$
\begin{array}{r}
4210 \pm 90 \\
\delta^{13} C=-28.6 \%
\end{array}
$$

Wood from low level wood structure at Rowland's Track, Ashcott Heath, Meare (51 ${ }^{\circ} 8^{\prime} 40^{\prime \prime} \mathrm{N}, 2^{\circ} 47^{\prime} 5^{\prime \prime} \mathrm{W}$, NGR: ST44983896) Comment (JMC): dates hurdle trackway in previously unknown area of Levels (Coles et al, 1977). Date corresponds well with Walton Heath series and helps reinforce archaeol suggestion of exact contemporaneity of Rowland's Track and Walton Heath series.

HAR-1467. SLP757 Part A

$$
\begin{array}{r}
4330 \pm \mathbf{9 0} \\
\delta^{13} C=-29.3 \% \\
\mathbf{4 2 5 0} \pm \mathbf{9 0} \\
\delta^{13} C=-26.7 \%
\end{array}
$$

HAR-1468. SLP757 Part B

Wood, coppiced hazel and alder, from newly discovered wooden structure in low level peat at Walton Heath II.2, Meare $\left(51^{\circ} 8^{\prime} 50^{\prime \prime} \mathrm{N}\right.$, $2^{\circ} 46^{\prime} 45^{\prime \prime}$ W, NGR: ST45363934). Comments: samples A and B dated separately. (JMC): results date earliest surviving hurdles, made of coppiced hazel, alder, and willow, known from Britain (Coles et al, 1977, p 10).

HAR-1470. SLP758 Part 1

$$
\begin{array}{r}
\mathbf{4 2 5 0} \pm \mathbf{8 0} \\
\delta^{1 s} C=-29.8 \%
\end{array}
$$


HAR-1471. SLP758 Part 2

Wood, age 4-8 yr growth from lowest level wood beneath Walton Track structure at Walton 4.108, Meare $\left(51^{\circ} 8^{\prime} 50^{\prime \prime} \mathrm{N}, 2^{\circ} 46^{\prime} 45^{\prime \prime} \mathrm{W}\right.$, NGR: ST45363934). Comment (JMC): dates commencement of wooden structure on Walton Heath (Coles et al, 1977). Good agreement with HAR-1220.

\section{Sweet Track series}

As part of dendrochronol studies included in Somerset Levels project, a number of samples from Neolithic Sweet Track were subm for dating. Each sample, covering 15 annual rings, was selected from 40-yr intervals of 314-yr floating tree-ring chronology established on 129 oak timbers from this track. Samples subm to date, as closely as possible, felling of timber and track's construction. Track runs S-N across Levels, probably from Polden Hills to Meare-Westhay I.; all samples are from Sweet Track R at Shapwick. For detailed discussion of Sweet track, see Coles \& Orme $(1976 ; 1979)$. For description of tree-ring studies and further discussion of date results, see Morgan $(1976 ; 1979)$. (Note: results are arranged in order, according to tree-ring sequence, not numerically, according to lab ref no.).

\section{HAR-1379. SLP759}

$$
\begin{array}{r}
\mathbf{4 5 5 0} \pm \mathbf{7 0} \\
\delta^{13} C=-27.2 \%
\end{array}
$$

Wood from annual rings 58 to 73 (earliest) of tree-ring sequence. Includes secs cut from 9 timbers. Comment (JMC): younger than expected; should antedate site's construction $>300 \mathrm{yr}$.

\section{HAR-1472. SLP7510 Part 1}

$$
\begin{array}{r}
\mathbf{5 0 7 0} \pm \mathbf{8 0} \\
\delta^{13} C=-26.2 \%
\end{array}
$$

Wood from annual rings 98 to 113 ; includes secs cut from 16 timbers. Comments: rootlets and insect infestation in original material. (JMC): corresponds well with site and date and expected date from treering evidence.

\section{HAR-1473. SLP7510 Part 2}

$$
\begin{array}{r}
4940 \pm 150 \\
\delta^{13} C=-27.2 \% 0
\end{array}
$$

Wood from annual rings 98 to 113. Comment: unreliable result determined from residue re-burn after zero result in acetylene preparation stage. (JMC): younger than expected.

HAR-1475. SLP7511 Part 1

$$
\begin{array}{r}
\mathbf{5 0 2 0} \pm \mathbf{1 0 0} \\
\delta^{13} C=-27.3 \% \\
\mathbf{5 1 1 0} \pm \mathbf{9 0} \\
\delta^{13} C=-26.6 \% 0
\end{array}
$$$$
\text { HAR-1476. SLP7511 Part } 2
$$

Wood from annual rings 138 to 153; includes secs cut from 11 timbers. Comment: rootlets and insect contamination in original material. (JMC): consistent with site date and tree-ring series. 
HAR-1477. SLP7512 Part 1

Wood from annual rings 178 to 193; includes secs cut from 12 timbers. Comment: rootlets and insect contamination in original material. (JMC): date rejected.

HAR-1478. SLP7512 Part 2

Wood from annual rings 178 to 193. Comment (JMC): slightly younger than expected.

HAR-1384. SLP7513 Part 1

$$
\begin{array}{r}
\mathbf{5 0 3 0} \pm \mathbf{9 0} \\
\delta^{13} C=-27.1 \% \text { \% }
\end{array}
$$

HAR-1469. SLP7513 Part 2

$5110 \pm 90$

$\delta^{13} \mathrm{C}=-27.0 \%$

Wood from annual rings 218 to 233; includes secs from 12 timbers. Comment (JMC): both results are consistent with site date and tree-ring series.

HAR-1479. SLP7514 Part 1

$$
\begin{array}{r}
4710 \pm 100 \\
\delta^{13} C=-27.2 \% \\
\mathbf{4 8 7 0} \pm \mathbf{8 0} \\
\delta^{13} C=-26.6 \%
\end{array}
$$

HAR-1480. SLP7514 Part 2

Wood from annual rings 258 to 273; includes secs cut from 9 timbers. Comment: rootlets and insect contamination in original material. (JMC): HAR-1479 is slightly younger than expected; HAR-1480 is consistent with site date and tree-ring series.

\section{Pentre series}

Samples taken from Bronze age composite mound at Pentre Farm, Pontardulais, West Glamorgan, Wales $\left(51^{\circ} 42^{\prime} 25^{\prime \prime} \mathrm{N}, 4^{\circ} 1^{\prime} 45^{\prime \prime} \mathrm{W}\right.$, NGR: SN59150265). Samples coll July 1974 and subm Nov 1974 by A H Ward. See Ward (1975) for interim report on excavation and Ward (1978) for final report.

\section{HAR-958. P14}

$$
\begin{array}{r}
\mathbf{3 4 7 0} \pm \mathbf{7 0} \\
\delta^{13} C=-24.6 \%
\end{array}
$$

Charcoal, AML 749316, recovered from pit cut into earth mound that also contained cremated bone. Pit was sealed beneath stones of cairn cap covering mound. Comment (AHW): result corresponds well with structural style of monument interpreted as early Bronze age ritual site.

\section{HAR-959. P113}

$$
\begin{array}{r}
\mathbf{1 5 0 0} \pm \mathbf{7 0} \\
\delta^{13} C=-26.7 \% 0
\end{array}
$$

Charcoal, AML 749317, from large pit outside edge of mound. Three successive layers of burning in pit were apparent; sample was taken solely from upper layer. Comment (AHW): on this late Roman - early 
Post-Roman date, feature cannot be assoc with barrow. Possible interpretation-temporary native camp of that period.

\section{Poundbury series}

Samples from a multi-phase settlement dating from late Neolithic to Post-Roman period at Poundbury, Dorchester, Dorset, England (50 $42^{\prime}$ $\mathrm{N}, 2^{\circ} 30^{\prime} \mathrm{W}$, NGR: SY685911). For interim report on excavations, see Green (1974). Samples coll Aug 1971 by J Beavis, HAR-993, -994, and Sept 1973 by H G Pell, HAR-995, -996; subm Jan 1975 by C J S Green, Dorchester Excavations Comm.

\section{HAR-993. CH.93}

$$
\begin{array}{r}
\mathbf{3 3 8 0} \pm \mathbf{9 0} \\
\delta^{13} C=-25.3 \% \text { }
\end{array}
$$

Charcoal, AML 749181, from fill of post-hole within area of Late Neolithic to Middle Bronze age occupation. Comment (CJSG): sample from 1 of several post-holes on $\mathrm{W}$ side of Middle Bronze age settlement area. Result would fall within early Middle Bronze age of this region, somewhat early for main Deverel-Rimbury settlement but compatible with earliest phase.

HAR-994. CH.100

$$
\begin{array}{r}
\mathbf{3 0 3 0} \pm \mathbf{9 0} \\
\delta^{18} C=-27.2 \% \text { ? }
\end{array}
$$

Charcoal, AML 749182, from base fill of V-cut ditch demarcating $\mathrm{S}$ side of Middle Bronze age settlement. Comment (CJSG): sample immediately antedates filling-in of ditch and presumed abandonment of Deverel-Rimbury settlement. Result falls midway between determinations for similar settlements at Shearplace Hill, Dorset and Itford Hill, Sussex and is a useful addition to dates for these rare sites.

HAR-995. CH137 (a)

$$
\begin{array}{r}
1880 \pm 70 \\
\delta^{13} C=-24.7 \% o
\end{array}
$$

Charcoal, AML 749183, from layer of burning and occupation debris in bottom of sunken-floored hut of early Saxon type. Comment (CJSG): both character of feature from which sample was derived and date relative to underlying late Roman cemetery suggest date range for this feature of early 5th to 8th centuries AD. Sample contamination or origin from old timber must be considered.

HAR-996. CH137 (b)

$$
\begin{array}{r}
\mathbf{2 4 0 0} \pm \mathbf{7 0} \\
\delta^{13} \mathrm{C}=-22.9 \%
\end{array}
$$

Charcoal, AML 749184, from same context as HAR-995. Comment (CJSG): see HAR-995.

\section{Brenig Valley series}

Samples from some monuments in Early Bronze age cemetery and from other excavations in Brenig Valley, Clwyd, North Wales $\left(53^{\circ} 6^{\prime} \mathrm{N}\right.$, $3^{\circ} 31^{\prime} \mathrm{W}$, NGR: SH980570). Interim report on round barrows, ring cairn, and earlier Mesolithic occupation in Lynch et al (1974) and Lynch and Allen (1975). 


\section{HAR-1027. BG734542. BRENIG 45 (round barrow)}

Soil from contents of small Collared urn containing infant earbones. Urn was buried in palisade trench surrounding barrow and must be either contemporary or later than barrow. Comment (FL): date agrees with building of barrow (see HAR-712, -657: $3620 \pm 60,3570 \pm 100$ ) but does not agree well with HAR-658 qv (3290 \pm 70$)$ which suggested palisade was later addition, са 1340 вс. Stratigraphic judgements need reconsideration.

\section{HAR-1133. B44PA323. BRENIG 44 (ring cairn) $\quad 3500 \pm 80$ $\delta^{13} C=-25.3 \%$}

Charcoal from lower fill of Pit A cut from old ground surface later than HAR-501 qv (R, 1977, v 19, p 411). Comment (FL): slightly later than expected in view of HAR-501 $(3630 \pm 100)$ but relevant sequence is correct.

\section{HAR-1136. B44F5123. BRENIG 44}

$$
\begin{array}{r}
2960 \pm 70 \\
\delta^{13} C=-26.0 \% \text {. }
\end{array}
$$

Charcoal from burning on pared old ground surface, interior of ring. Comment (FL): date seems incorrect. Charcoal was covered by inner bank built before 1550 BC, see HAR-505 (R, 1977, v 19, p 412) and HAR-1133. Date seems too late in cemetery sequence as a whole.

\section{HAR-1137. B44PA133. BRENIG 44}

$$
\begin{array}{r}
\mathbf{3 3 3 0} \pm \mathbf{7 0} \\
\delta^{13} C=-24.8 \% \%
\end{array}
$$

Charcoal from Pit A, upper fill, possibly re-cut from Layer 3. Comment (FL): date, although not significantly different from HAR-1133 qv for lower fill of this pit, is in right sequence and helps confirm archaeol evidence for re-cut. Agrees well with HAR-504, (R, 1977, v 19, p 412) and HAR-1138 for other pits dug from this level.

\section{HAR-1138. B44PB133. BRENIG 44}

$$
\begin{array}{r}
3290 \pm \mathbf{8 0} \\
\delta^{13} C=-25.4 \% 0
\end{array}
$$

Charcoal from Pit B, Layer 3 of internal activity. Slightly later than re-cutting of Pit A, archaeologically. Comment (FL): date is appropriate. In view of strat relationship to re-cutting of Pit A, slightly later date was expected, but sequence is correct.

\section{HAR-1134. BR470E57. BRENIG 47 (round cairn )}

$$
\begin{array}{r}
\mathbf{4 0 9 0} \pm \mathbf{7 0} \\
\delta^{13} C=-25.5 \%
\end{array}
$$

Charcoal from old ground surface beneath stone skirt. Comment (FL): earlier than expected, but not inappropriate. Thought to be earliest monument in cemetery, but date ca 1800 BC was hazarded. 
HAR-1135. BR45E9P1. BRENIG 53

$7300 \pm 100$

$\delta^{13} \mathrm{C}=-29.4 \%$

Charcoal from lower parts of fire pit. Comment (FL): sample from pits assoc with Mesolithic flint work and suits that assemblage. Agrees well with HAR-656 $(7650 \pm 80)$ which dates unassoc pit on other side of valley.

HAR-1434. BG3100

$4780 \pm 160$

$\delta^{13} \mathrm{C}=-25.9 \%$

Charcoal from posthole in corner of 1975 excavation on fringe of Mesolithic occupation area but also close to 2 Bronze age monuments (BG44 \& BG45) (53 6' 25" N, 3० 31' W, NGR: SH982572). Comment: small sample accounts for larger than normal error term.

HAR-1435. BG480723

$$
\begin{array}{r}
\mathbf{3 3 0} \pm \mathbf{7 0} \\
\delta^{13} \mathrm{C}=-26.7 \% 0
\end{array}
$$

Charcoal from small pit at Brenig Valley Post-Medieval site $\left(53^{\circ} 6^{\prime}\right.$ $30^{\prime \prime} \mathrm{N}, 3^{\circ} 30^{\prime} 25^{\prime \prime} \mathrm{W}$, NGR: SH988575) sealed beneath stone wall foundation of ?16th century AD, Hafoty Welsh summer farm (Allen, 1974). Comment (DWHA): pit and its neighbours were contemporary with period of activity represented by wall that sealed it.

\section{HAR-1436. BG5328}

$$
\begin{array}{r}
\mathbf{5 1 2 0} \pm \mathbf{1 0 0} \\
\delta^{13} C=-27.9 \%
\end{array}
$$

Charcoal from 1 of at least 8 hearths or fire-pits assoc with stakeholes and quantities of flint and chert, which formed basis of area of possible Mesolithic occupation in Brenig Valley (53 $6^{\prime} 25^{\prime \prime} \mathrm{N}, 30^{\circ} 31^{\prime} \mathrm{W}$, NGR: SH982572).

\section{Odell series}

Site at Odell, Bedfordshire, England $\left(52^{\circ} 12^{\prime} 5^{\prime \prime} \mathrm{N}, 0^{\circ} 35^{\prime} 45^{\prime \prime} \mathrm{W}\right.$, NGR: SP956568). Samples coll 1974 and 1975 and subm 1975 by B Dix. Full report on site is forthcoming in Bedfordshire Archaeol Jour 16.

\section{HAR-1038. ODLSWT19}

$$
\begin{array}{r}
1230 \pm 70 \\
\delta^{13} C=-27.5 \%
\end{array}
$$

Wood, AML 750910, from timber well. Sample formed integral part of structure; it was 1 of 4 piles around which lining was constructed (Dix, 1975a,b). Comment (BD): date consistent with archaeol expectations.

\section{HAR-1427. 74F123S7}

$$
\begin{array}{r}
1240 \pm 80 \\
\delta^{13} C=-28.7 \% 0
\end{array}
$$

Wood, AML 756482, id by C A Keepax as probably Hazel or Alder, from stake from outer lining of well and formerly driven into natural side of well pit (Dix, 1975b; 1979). Comment (BD): cf HAR-1428 and -1838 , below, which are from same well structure. This slightly more recent measurement may represent replacement of stake in outer lining. 
HAR-1428. 74F123WB

$$
\begin{array}{r}
1390 \pm \mathbf{7 0} \\
\delta^{13} C=-28.3 \%
\end{array}
$$

Wood, AML 75648, id by C A Keepax, as Willow twigs of 1-yr growth, from part of wicker basket forming integral part of well structure and around which silts had accumulated ( $c f$ Medieval Archaeol, v. 21, 1977, p 204 and pl XV1A; Dix, 1975b, 1979). Comment (BD): date consistent with archaeol expectations.

HAR-1838. 74F123TA

$$
\begin{array}{r}
1350 \pm \mathbf{7 0} \\
\delta^{13} C=-26.4 \% o
\end{array}
$$

Wood, AML 756481, id as Oak, from plank, possibly re-used timber, that, with others, formed platform for access to well (Dix, 1975b; 1979). Comment (BD): date consistent with archaeol expectations.

\section{Little Waltham series}

Samples from Little Waltham, Essex, England, $\left(51^{\circ} 47^{\prime} 15^{\prime \prime} \mathrm{N}, 0^{\circ} 28^{\prime}\right.$ 45" E, NGR: TL736129). Coll 1971 and subm 1974, 1975 by P J Drury, Chelmsford Excavations Comm (Drury, 1973).

\section{HAR-1047. LWALTHAM}

$$
\begin{array}{r}
\mathbf{3 3 6 0} \pm \mathbf{8 0} \\
\delta^{13} C=-28.2 \% \text { o }
\end{array}
$$

Soil, AML 740542, consisting of organic material mixed with silt from lowest level of silt in former channel of $\mathrm{R}$ Chelmer (Old River Channel Layer 4). Comment (PJD): result seems reasonable, other evidence for date of this feature is scanty.

\section{HAR-1081. C11-1 (a)}

$$
\begin{array}{r}
\mathbf{2 5 6 0} \pm \mathbf{8 0} \\
\delta^{13} C=-26.1 \% \text { o }
\end{array}
$$

Soil, AML 729551, from burnt debris in Iron age hut wall trench. Comment (PJD): too early, sample came from same context as HAR1088 and -1120 qv. Presumably contaminated by residual material.

\section{HAR-1082. C11-1 (b)}

$$
\begin{array}{r}
3340 \pm 90 \\
\delta^{1 s} C=-25.6 \% \text { o }
\end{array}
$$

Soil, AML 729550, from burnt debris in Iron age hut wall trench. Comment (PJD): as for HAR-1081.

\section{HAR-1087. LW 71251-1}

$$
\begin{array}{r}
\mathbf{5 1 2 0} \pm \mathbf{1 3 0} \\
\delta^{13} C=-25.4 \% \text { o }
\end{array}
$$

Soil, AML 729554, from Neolithic hearth. Comment (PJD): date fits pottery from feature which is plain Neolithic.

\section{HAR-1088. C11-3}

$$
\begin{array}{r}
\mathbf{2 1 6 0} \pm \mathbf{8 0} \\
\delta^{13} C=-25.1 \% \text { o }
\end{array}
$$

Soil, AML 729552, from wall trench of Iron age circular hut probably destroyed by fire. 
HAR-1120. C11-34E

$2100 \pm 70$

$\delta^{13} \mathrm{C}=-25.1 \%$

Charcoal, AML 759553, from wall trench of Iron age circular hut, probably destroyed by fire. Comment (PJD): result, with that of HAR1088, above, suggests date in mid-3rd century BC for Iron age settlement. Accords well with archaeol evidence from site.

\section{Fullers Hill series}

Samples from excavations (Rogerson, 1976) at Fullers Hill, Great

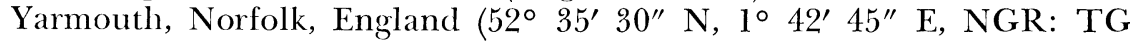
52250796). Coll and subm Jan 1975 by A Rogerson, Norfolk Archaeol Unit.

\section{HAR-1079. 1032.197}

$$
\begin{array}{r}
\mathbf{8 9 0} \pm \mathbf{7 0} \\
\delta^{13} C=-26.8 \% \text { \% }
\end{array}
$$

Ciharcoal, AML 749530, probably bldg material, from surface of clay floor sealed below thick layer of charcoal, itself sealed by wind-blown sand. Excavation Phase IX.

\section{HAR-1080. 1032.306}

$$
\begin{array}{r}
1010 \pm 70 \\
\delta^{13} C=-25.1 \% 0
\end{array}
$$

Charcoal, AML 749531, from layer of probable bldg material overlying clay and soil floor and sealed below layer of wind-blown sand Excavation Phase VI.

General Comment (AR): on general archaeol grounds, both dates seem ca $100 \mathrm{yr}$ too early. This is perhaps to be expected of charcoal from large timbers. For HAR-1080, one coin, AD 1042-1066, occurred in phase but apart from this chronology is entirely floating and, although stratigraphy was very clear, pottery was only other aid to dating. Within 2 standard deviations, results fall within expected range.

\section{Moel y Gaer series}

Samples from Moel y Gaer (Guilbert, 1975a,b; 1976) Rhosesmor, Clwyd, North Wales (53 12' N, $3^{\circ} 11^{\prime} \mathrm{W}$, NGR: SJ211690).

HAR-1122. MO470

$$
\begin{array}{r}
2210 \pm 70 \\
\delta^{1 s} C=-25.3 \%
\end{array}
$$

Charcoal, id as mixture of Corylus avellana and Crataegus sp, both ca $10 \mathrm{yr}$ old, found as isolated patch in core of Phase 2, timber-framed Rampart A. Comment (GG): at worst, sample provides terminus post quem for construction of this rampart, not structural timber in situ.

HAR-1125. M1838

$$
\begin{array}{r}
\mathbf{2 4 3 0} \pm \mathbf{1 4 0} \\
\delta^{1 s} C=-25.9 \%
\end{array}
$$

Charcoal, id as Quercus sp, 10+ yr old, with Corylus avellana, ca 10 yr old, from posthole which held one side of door frame into stake-wall round house of Phase 2 settlement. Charcoal derived from post pipe, ca $0.20 \mathrm{~m}$ diam, that was largely back-filled with stones. Comment (GG): not structural timber in situ. 
HAR-1126. M0316

Charcoal, id as Corylus avellana, ca $10 \mathrm{yr}$ old, from dark gray clay filling of posthole belonging to porch of post-ring round-house. Comment (GG): result is compatible with HAR-606 $(2570 \pm 70$, R, 1977, v 19, p 414) derived from another round house that was thought, on archaeol grounds, to be broadly contemporary with this one.

\section{HAR-1127. M1071}

$$
\begin{array}{r}
\mathbf{2 6 6 0} \pm \mathbf{7 0} \\
\delta^{13} \mathrm{C}=-24.8 \% \text { 。 }
\end{array}
$$

Charcoal, id as Quercus sp, 50 or more yr old. Sample from 1 of ring of 12 small pits, each comprehensively blocked with stones, together comprising anomalous structure of $6.4 \mathrm{~m}$ diam. Comment: heavy rootlet contamination.

HAR-1293. M1423-25

$$
\begin{array}{r}
2350 \pm 90 \\
\delta^{13} C=-25.9 \%
\end{array}
$$

Charcoal, id as mixture of Corylus avellana, Fraxinus exelsior, and Populus sp, all ca $10 \mathrm{yr}$ old. Sample was mixture from 3 postholes of entrance porch of post-ring round house. Comment (GG): probably not structural timbers in situ.

\section{HAR-1294. M1479}

$$
\begin{array}{r}
\mathbf{2 3 8 0} \pm \mathbf{7 0} \\
\delta^{13} C=-25.5 \%
\end{array}
$$

Charcoal, id as mixture of Corylus avellana, min $10 \mathrm{yr}$ old and Quercus sp, 20 to $50 \mathrm{yr}$ old. Sample derived from silt filling of postremoval-hole dug into top of posthole of large four-poster belonging to grid layout of Phase 2 settlement. Comment: heavy rootlet contamination.

\section{HAR-1353. M1605/17}

$$
\begin{array}{r}
\mathbf{2 3 9 0} \pm \mathbf{8 0} \\
\delta^{13} C=-25.0 \%
\end{array}
$$

Charcoal, id as mixture of Corylus avellana, up to $20 \mathrm{yr}$ old with Quercus sp ca $25 \mathrm{yr}$ and Fraxinus ca $10 \mathrm{yr}$. Sample derived from silt filling of post pipes of 4 different postholes (M1605, M1607, M1611, and M1617) of single post-ring round house. Comments: charcoal contained gravel pieces and rootlet contamination. (GG): probably not structural timbers in situ.

\section{Wighton series}

Samples from excavation of D-shaped enclosure located 1974 (Lawson, 1976) at Whey Curd Farm, Wighton, Norfolk (52 $54^{\prime} 20^{\prime \prime} \mathrm{N}, 0^{\circ} 53^{\prime}$ 55" E, NGR: TF944384). Coll Sept 1974 and subm April 1975 by A J Lawson.

\section{HAR-1142. 1113WGTA}

$$
\begin{array}{r}
1710 \pm 70 \\
\delta^{13} C=-20.0 \% 0
\end{array}
$$

Human bone, AML 753036, from Skeleton 19, 1 of 5 from graves sealed by old ground surface beneath bank. Comment (AJL): result agrees with very meagre archaeol evidence. 
HAR-1143. 1113WGTB

$1900 \pm 120$

$\delta^{13} C=-22.1 \%$

Animal bone, AML 753037, from silting of small ditch sealed by enclosure bank Comment (AJL): pottery from same context could be late lst century.

\section{NVRC series}

Samples from multiple round barrow (Donaldson, 1977) at Barnack Cambridgeshire, England (52॰ 39' N, $0^{\circ} 26^{\prime} 45^{\prime \prime}$ E, NGR: 'TF050069). Coll Dec 1974 and subm April 1975 by P Donaldson.

\section{HAR-1156. BGP1497}

Bone, from secondary burial.

$$
\begin{array}{r}
\mathbf{3 2 3 0} \pm \mathbf{1 0 0} \\
\delta^{13} C=-20.8 \%
\end{array}
$$

\section{HAR-1158. BGP1496}

Bone, from secondary burial.

$$
\begin{array}{r}
\mathbf{3 8 0 0} \pm \mathbf{1 0 0} \\
\delta^{1 s} C=-21.4 \% \text { o }
\end{array}
$$

\section{HAR-1205. BGP1499}

Bone, from secondary burial.

$$
\begin{array}{r}
\mathbf{3 5 9 0} \pm \mathbf{8 0} \\
\delta^{1 s} C=-21.6 \% \text { \% }
\end{array}
$$

\section{HAR-1207. BGP1501}

Bone, from secondary burial.

$$
\begin{array}{r}
\mathbf{3 4 0 0} \pm \mathbf{8 0} \\
\delta^{13} C=-21.6 \%
\end{array}
$$

\section{HAR-1430. BGP1498}

Bone, from secondary burial.

$$
\begin{array}{r}
\mathbf{3 4 5 0} \pm \mathbf{7 0} \\
\delta^{13} C=-22.4 \% \text { \% }
\end{array}
$$

HAR-1612. BGP2442

$$
\begin{array}{r}
\mathbf{3 2 9 0} \pm \mathbf{8 0} \\
\delta^{13} C=-21.9 \%
\end{array}
$$

Human bone, from secondary burial. Comment: replicate check measurement on HAR-1206.

\section{HAR-1645. BGP1450}

$$
\begin{array}{r}
\mathbf{3 5 7 0} \pm \mathbf{~ 8 0} \\
\delta^{13} C=-24.8 \% \text { 。 }
\end{array}
$$

Charcoal, AML 757633, id by C Keepax as Oak from large timbers from beside primary inhumation. Coll Feb 1975 and subm May 1976.

\section{HAR-1163. SP74F3}

$$
\begin{array}{r}
\mathbf{3 2 9 0} \pm \mathbf{1 3 0} \\
\delta^{13} C=-26.5 \%
\end{array}
$$

Charcoal, AML 751850, from small pit, containing human cremation, cut into gravel and sealed beneath build-up of marsh clay, at Site 2, Devil's Wood, Sproughton, Suffolk, England (52० 3' $35^{\prime \prime}$ N, $1^{\circ} 7^{\prime}$ E, NGR: TM13364447). Coll April 1974 and subm April 1975 by E A Martin, Suffolk Archaeol Unit. Comments: small sample, needed topping up with inactive $\mathrm{CO}_{2}$ to enable measurement. (EAM): pit lay in middle of late Neolithic/early Bronze age settlement site (rept forthcoming in East Anglian Archaeol). 


\section{HAR-1192. HC75F312}

$$
\begin{array}{r}
\mathbf{2 3 1 0} \pm \mathbf{7 0} \\
\delta^{13} \mathrm{C}=-26.1 \%
\end{array}
$$

Charcoal, AML 753125, from oval pit containing many heavily burned river pebbles and pot sherds at Holm Castle, Windmill Hill,

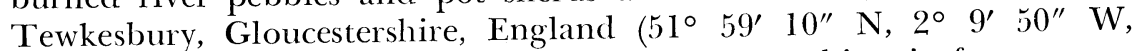
NGR: SO887321). Pit was part of complex of prehistoric features exposed by removal of topsoil, Medieval occupation levels and 60 to $80 \mathrm{~cm}$ clay. Coll April 1975 by R L Hall; subm May 1975 by A Hannan, Dir Excavations, Tewkesbury Borough Council. Comment (AH): conditions prevailing during uncovering of large area of prehistoric ditches and pits and fragmentary state of pottery recovered made radiocabon date important. Initial comparison with pottery fabrics in North Gloucestershire pointed to Late Neolithic-Mid-Bronze age. Result permits broader approach to material.

\section{HAR-1198. CHN74}

$$
\begin{array}{r}
\mathbf{5 2 7 0} \pm \mathbf{1 1 0} \\
\delta^{13} \mathrm{C}=-25.3 \%
\end{array}
$$

Charcoal, from upper filling of Neolithic shaft (Bradley et al, 1975/ 6) at Cannon Hill, Bray, Berkshire, England (51 $30^{\prime} 15^{\prime \prime} \mathrm{N}, 0^{\circ} 42^{\prime} 20^{\prime \prime}$ W, NGR: SU89647926). Coll 1974 and subm May 1975 by R F Weng, Maidenhead Archaeol \& Hist Soc. Comment (RFW): assoc occupation debris contained Grimston/Lyles Hill Ware, unfired clay, bone fragments and both Neolithic and Mesolithic flints. Shaft tentatively interpreted as a well and is earliest directly dated example in Britain.

HAR-1199. S62

$$
\begin{array}{r}
\mathbf{3 7 5 0} \pm \mathbf{8 0} \\
\delta^{13} C=-26.2 \%
\end{array}
$$

Charcoal from large, deep pit, in centre of henge at Milfield North Henge Monument, Northumberland (55 $36^{\prime} 30^{\prime \prime}$ N, $2^{\circ} 6^{\prime} 45^{\prime \prime} \mathrm{W}$, NGR: NT934349). Coll April 1975 and subm May 1975 by A F Harding, Dept Archaeol, Univ Durham. Comment (AFH): presumably part of primary construction and perhaps contemporary with sherds of Beaker-Food Vessel from adjacent pit.

\section{HAR-1201. BC75/3}

Wood, AML 751142, from base plate of possible Medieval waterfront (Hill et al, in press; Hobley \& Schofield, 1977) at Baynards Castle $\left(51^{\circ} 28^{\prime} 30^{\prime \prime} \mathrm{N}, 0^{\circ} 4^{\prime} 30^{\prime \prime} \mathrm{W}, \mathrm{NGR}\right.$ : TQ31888093). Coll and subm April 1975 by B Hobley, Chief Urban Achaeol, Mus London.

\section{Northampton series}

Samples from St Peter's St, Northampton ( $52^{\circ} 13^{\prime} 55^{\prime \prime} \mathrm{N}, 0^{\circ} 54^{\prime} 55^{\prime \prime}$ W, NGR: SP750603). Interim report on this site appears in Williams (1975). Samples coll Jan and Feb 1974; subm June 1975 by J Williams, Northampton Development Corp. 
HAR-1225. M1152854

$$
1190 \pm 70
$$

$\delta^{13} C=-26.2 \%$

Soil containing charcoal, AML 753363, from layer within fill of Grubenhaus Phase IV, late Saxon period. Comment (JW): date probably 50 to 100 yr early.

\section{HAR-1244. M1153302}

$$
\begin{array}{r}
1110 \pm \mathbf{8 0} \\
\delta^{t s} C=-22.3 \%
\end{array}
$$

Bone, AML 753364, from gully, ca $1 \mathrm{~m}$ wide by $0.60 \mathrm{~m}$ deep, with sandy fill, cut into weathered ironstone bedrock.

\section{HAR-1245. M1153303}

$$
\begin{array}{r}
1300 \pm 60 \\
\delta^{13} C=-22.3 \%
\end{array}
$$

Bone, AML 753365, from Phase III B, destruction of concrete mixers, possibly late Saxon period, sand and mortar spreads, varying from a few $\mathrm{cm}$ to $0.5 \mathrm{~cm}$, overlay mixers.

\section{HAR-1246. M1153304}

$$
\begin{array}{r}
1310 \pm 90 \\
\delta^{13} C=-22.3 \%
\end{array}
$$

Bone, AML 753366, from destruction of concrete mixers. Comment (JW): from same level as HAR-1245, above.

\section{Hereford series}

\section{HAR-1260. HE74A380}

$$
\begin{array}{r}
\mathbf{8 7 0} \pm \mathbf{8 0} \\
\delta^{13} C=-22.3 \%
\end{array}
$$

Animal bone, AML 753183, from fill of small ditch apparently sealed by gravel rampart (Shoesmith, in press) at Bewell House site, Hereford, England (52० 3' $30^{\prime \prime} \mathrm{N}, 2^{\circ} 43^{\prime} \mathrm{W}$, NGR: SO507401). Coll June 1975 and subm July 1975 by R Shoesmith, City Hereford Archaeol Comm. Comment (RS): sample of ditch silt nearby was taken for archaeomagnetic dating.

\section{HAR-1375. HE732F219/F270}

$$
990 \pm 70
$$

Accumulated sample, 2 parts combined, of charcoal be pre-turf rampart from Berington St Phase charcoal, which should Coll March 1973 and subm Sept 1975 b, Phase II, Hereford, England.

\section{HAR-1318. HS75HLJB}

$$
\begin{array}{r}
1540 \pm 90 \\
\delta^{13} C=-28.1 \%
\end{array}
$$

Wood, AML 756454, 1 of series, from silt deposit in $\mathrm{R}$ Thames at OD height (Newlyn) at Hays Lane Junction Box, London, England $\left(51^{\circ} 30^{\prime} 20^{\prime \prime} \mathrm{N}, 0^{\circ} 4^{\prime} 30^{\prime \prime} \mathrm{W}\right.$, NGR: TQ33018023). Coll April 1975 by A Graham; subm Oct 1975 by H Sheldon, Southwark Archaeol Excavation Comm. Comment (HS): date shows that $\mathrm{R}$ Thames was depositing clay at $\mathrm{OD}$ height in low area along $\mathrm{S}$ bank in late Roman or immediate Post-Roman period. 
GP 74 series

Samples from Iron age settlement site at Guiting Manor Farm, Guiting Power, Gloucestershire, England (51 $55^{\circ} 20^{\prime \prime} \mathrm{N}, 1^{\circ} 53^{\prime} 5^{\prime \prime} \mathrm{W}$, NGR: SP089250). Coll Nov 1974 and subm Oct 1975 by A Saville, Cheltenham Art Gallery \& Mus Service.

HAR-1320. C108 etc.

$6780 \pm 110$

$\delta^{13} C=-24.5 \%$

Charcoal, AML 756458, from fill of 7 pits (refs F1, F6, F7, F10, F11, F14, F23) assoc with Iron age pottery.

\section{HAR-1323. C110/114}

$\mathbf{3 7 8 0} \pm \mathbf{1 0 0}$

Charcoal, AML 756459, from fill of 2 pits (refs F3 and F5) assoc with Iron age pottery. Comment: small sample.

General Comment (AS): measurements inconsistent with context of samples, extracted from fills of Iron age storage/rubbish pits assoc with "Iron Age B'-type ceramics. On ceramic evidence, settlement presumably falls in range 300 to $0 \mathrm{BC}$.

\section{75 series}

Samples from Bronze age round barrow at Cow Common, Gloucestershire, England ( $51^{\circ} 55^{\prime} 5^{\prime \prime} \mathrm{N}, 1^{\circ} 48^{\prime} 10^{\prime \prime} \mathrm{W}$, NGR: SP13502625). Coll Jan 1975 and subm Oct 1975 by A Saville.

\section{HAR-1325. C19A}

$$
\begin{array}{r}
\mathbf{3 4 3 0} \pm \mathbf{8 0} \\
\delta^{1 s} G=-25.0 \%
\end{array}
$$

Charcoal, AML 756456, from centre of F3, also F8A.

\section{HAR-1326. C28A}

Charcoal, AML 756457, from centre of F3, also F8G.

General Comment (AS): samples were taken from burnt timbers overlying primary grave pit that contained unaccompanied cremation, at centre of ditchless round barrow. Results in 15th century BC fit Bronze age barrow well.

HAR-1339. W 103/4

$$
\begin{array}{r}
1600 \pm 80 \\
\delta^{13} C=-27.7 \%
\end{array}
$$

Wood (oak), AML 753163, underlying 4th century AD Roman City Wall (of Period 5) Gloucester (Site 46/74), England (51 $51^{\prime} 40^{\prime \prime} \mathrm{N}, 2^{\circ}$ 12' 30" W, NGR: SO835183). Coll Aug 1974 by C M Heighway; subm July 1975 by Excavation Unit, Gloucester (Heighway, 1976). Comment (CMH): sample of 25 sapwood rings from end of 85-yr tree-ring sequence. It was cut from 2 wooden piles that came from same tree.

HAR-1411. B18A EAST

$$
\begin{array}{r}
4560 \pm 70 \\
\delta^{1 s} C=-27.2 \% 0
\end{array}
$$

Charcoal, AML 680534, 680535, 680536, 30cm from base of inner of 2 concentric ditches of Neolithic mortuary enclosure (Jackson, 1976) at 
Aldwincle Neolithic site, Aldwincle, Northamptonshire, England ( $54^{\circ} 24^{\prime}$ $40^{\prime \prime} \mathrm{N}, 0^{\circ} 30^{\prime} 20^{\prime \prime} \mathrm{W}$, NGR: SP996803). Coll 1968 by D Jackson and L Biek; subm Dec 1975 by H Keeley.

\section{HAR-1420. RAD75/2/33}

$$
\begin{array}{r}
\mathbf{3 0 0 0} \pm \mathbf{9 0} \\
\delta^{13} C=-26.2 \% 0
\end{array}
$$

Charcoal, AML 756427, from Radwell ring ditch 2, Bedfordshire, England (52० $13^{\prime} 10^{\prime \prime} \mathrm{N}, 0^{\circ} 30^{\prime} 55^{\prime \prime} \mathrm{W}$, NGR: TL011588). Charcoal was mostly twiggy; many of very small fragments were unid. but Prunus sp and hawthorn type tentatively id by C A Keepax. Sample from basal silt above primary fill, but with concentration of Bronze age material. Coll July 1975; subm Nov 1975 by P J Woodward. Comment (PJW): date shows re-use of ring ditch in Middle Bronze age when earlier material was disturbed. Other parallels occur along $\mathrm{R}$ Ouse. Ring ditches at Roxton and Warren Farm, Milton Keynes had similarly dated clearance horizons.

\section{St Magnus series}

Samples from different dated waterfronts of $\mathrm{R}$ Thames at St Magnus, part of New Fresh Wharf site, Billingsgate, London $\left(51^{\circ} 30^{\prime} 40^{\prime \prime} \mathrm{N}, 0^{\circ} 4^{\prime}\right.$ 40" W, NGR: TQ32948067) Coll Aug 1975 by J Schofield; subm Nov 1975 by G H Wilcox, Mus London (Schofield \& Miller, 1976; Hobley \& Schofield, 1977; Miller, Schofield et al, Excavations at New Fresh Wharf 1974-1978, in press).

\section{HAR-1421. SM75213}

$$
\begin{array}{r}
1630 \pm 70 \\
\delta^{13} C=-27.0 \% \text { o }
\end{array}
$$

Wood (oak, id by C Keepax), AML 756477, from Roman pile assoc with waterfront structure on Thames. Comment (GHW): pottery and analogies for structure suggest earlier date.

HAR-1422. SM75171

$$
\begin{array}{r}
1080 \pm \mathbf{8 0} \\
\delta^{13} C=-28.2 \% \text { o }
\end{array}
$$

Wood (oak, id by G Keepax), AML 756476, from late Saxon vertical stake assoc with mid- to late Saxon waterfront. Comment (GHW): fits well with pottery and stratigraphic sequence.

\section{Bell Hotel series}

Samples from earliest post-Roman habitation levels on site of Roman forum at Gloucester (Hurst, 1972). Site excavated at 11-17 Southgate St, Gloucester, England (51 $49^{\prime} \mathrm{N}, 2^{\circ} 12^{\prime} 20^{\prime \prime} \mathrm{W}$, NGR: SO832135). Coll 1968 and subm Nov 1975 by H Hurst.

\section{HAR-1443. 85/68 II}

$$
\begin{array}{r}
1240 \pm 70 \\
\delta^{13} C=-29.9 \%
\end{array}
$$

Wood, AML 753160, from alder tree stump. Periods $6 / 7$ (tree cut down at start of, or very early in occupation sequence). 


\section{HAR-1444. 85/68 II}

$$
\begin{array}{r}
1160 \pm \mathbf{8 0} \\
\delta^{13} C=-27.1 \% 0
\end{array}
$$

Wood, AML 753160, from Wall M1, Period 7, earliest post-Roman bldg.

HAR-1446. 85/68 XXI

$$
\begin{array}{r}
1300 \pm 70 \\
\delta^{13} C=-26.4 \% o
\end{array}
$$

Wood, AML 753160, from Timber A, W sec, from earliest habitation level.

\section{HAR-1636. 85/68 II}

$$
\begin{array}{r}
1160 \pm 70 \\
\delta^{13} C=-29.7 \% 0
\end{array}
$$

Replicate check measurement on HAR-1443.

General Coment (HH): earliest dating evidence for post-Roman occupation at centre of Gloucester.

\section{HAR-1448. CW75II29}

$$
\begin{array}{r}
\mathbf{3 4 8 0} \pm \mathbf{8 0} \\
\delta^{13} C=-25.8 \%
\end{array}
$$

Charcoal, AML 756528, from beaker spread on edge and over 1st Mound (Coombs, 1976) at Mortimer's Barrow 275, Callis Wold, Humberside (53 $59^{\prime} 25^{\prime \prime} \mathrm{N}, 0^{\circ} 4^{\prime} 45^{\prime \prime} \mathrm{W}$, NGR: SE832559). Coll Aug 1975 and subm Dec 1975 by D G Coombs, Dept Archaeol, Univ Manchester. Comment (DGC): date seems rather late for beakers represented in horizon. European evidence would suggest date nearer 2000 BC.

\section{Bridge-by-Pass series}

Samples from Late Bronze age barrow (Macpherson-Grant, 1977) at Bridge-by-Pass, Kent, England (59 $14^{\prime} 30^{\prime \prime} \mathrm{N}, 1^{\circ} 9^{\prime} 20^{\prime \prime} \mathrm{W}$, NGR: TR 19315331). Coll Sept 1974 and subm Jan 1976 by N Macpherson-Grant, Isle Thanet Archaeol Unit.

HAR-1492. SAMPLE A

$$
\begin{array}{r}
\mathbf{2 8 8 0} \pm \mathbf{8 0} \\
\delta^{13} C=-25.1 \% 0
\end{array}
$$

Charcoal, ca $25 \%$ id as Quercus sp, AML 749840, from Barrow 2, Cremation 7. Comment (NCM-G): apparently younger than Sample B (HAR-1493); latter was secondary burial outside barrow itself.

\section{HAR-1493. SAMPLE B} $2970 \pm 80$

Charcoal, AML 749850, from external Cremation 5. Comment (NCM-G): sample from external (extra-barrow) cremation assumed secondary to cremations within barrow.

General Comment (NCM-G): both dates fit fairly well with pottery styles, dating this barrow and both internal and external burials to Late Bronze age. This period is not yet clearly understood in East Kent.

\section{Ballygeardra series}

$$
\text { B. EIRE }
$$

Samples from horizontal mill site at Ballygeardra Townland, Co Killkenny $\left(52^{\circ} 28^{\prime} \mathrm{N}, 7^{\circ} 15^{\prime} \mathrm{W}\right)$. Coll by M F Ryan; subm Dec 1974 by A T Lucas, Dir, Natl Mus Ireland. 
HAR-1048. NMI-01

$1310 \pm 70$

Wood, part of beam.

HAR-1049. NMI-02

$1330 \pm 90$

Wood, part of chute.

HAR-1050. NMI-03

$$
1450 \pm 60
$$

Wood, part of timber balk.

$\delta^{13} \mathrm{C}=-28.0 \%$

\section{Knocknagranshy series}

Samples from horizontal mill site (Lucas, 1969) at Knocknagranshy Townland, Co Limerick (52 $\left.32^{\prime} \mathrm{N}, 8^{\circ} 40^{\prime} \mathrm{W}\right)$. Coll May 1955 and subm Dec 1974 by A T Lucas.

\section{HAR-1051. NMI-04}

$$
\begin{array}{r}
1200 \pm \mathbf{7 0} \\
\delta^{13} C=-26.2 \%
\end{array}
$$

Wood, part of chute.

HAR-1052. NMI-05

$$
\begin{array}{r}
1110 \pm 70 \\
\delta^{13} C=-27.5 \%
\end{array}
$$

Wood, part of large beam that supported fore end of chute.

\section{HAR-1053. NMI-06}

$$
\begin{array}{r}
1150 \pm \mathbf{5 0} \\
\delta^{1 s} C=-26.7 \%
\end{array}
$$

Wood from footbeam of mill investigated by A T Lucas, June 1973 at Knocknacroy Townland, Co Sligo (54 $4^{\circ}$ N, $\left.8^{\circ} 27^{\prime} \mathrm{W}\right)$. Subm Dec 1974 by A T Lucas.

\section{HAR-1054. NMI-07}

$$
\begin{array}{r}
1200 \pm 60 \\
\delta^{18} C=-27.4 \%
\end{array}
$$

Wood from chute of horizontal mill discovered in moory ground some years prior to 1872 (Wakeman, 1872-3) at Rossorry Townland, Co Fermanagh $\left(54^{\circ} 20^{\prime} \mathrm{N}, 7^{\circ} 38^{\prime} \mathrm{W}\right)$. Subm Dec 1974 by A T Lucas.

\section{HAR-1055. NMI-08}

$$
\begin{array}{r}
1350 \pm 70 \\
\delta^{13} C=-27.0 \%
\end{array}
$$

Wood from chute of horizontal mill at Toberaquill Townland, Co Westmeath $\left(50^{\circ} 35^{\prime} \mathrm{N}, 7^{\circ} 15^{\prime} \mathrm{W}\right)$. Coll Dec 1965 by A B O'Riordain; subm Dec 1974 by A T Lucas.

\section{HAR-1056. NMI-09}

$$
\mathbf{8 8 0} \pm \mathbf{8 0}
$$

Wood from foot beam of house built in stave-cum-plank technique in Medieval horizon at Christ Church Place, Dublin City $\left(53^{\circ} 20^{\prime} \mathrm{N}\right.$, $\left.6^{\circ} 16^{\prime} \mathrm{W}\right)$. Coll by A B O'Riordain; subm Dec 1974 by A $\mathrm{T}$ Lucas. Comment (ATL): result agrees with evidence from assoc coin finds. 
HAR-1144. NMI-10

$$
\begin{array}{r}
1090 \pm 70 \\
\delta^{13} C=-25.7 \% \text { o }
\end{array}
$$

Wood from mortised beam of horizontal mill excavated by Natl Mus Ireland at Boherduff Townland, Co Galway $\left(53^{\circ} 11^{\prime} \mathrm{N}, 3^{\circ} 38^{\prime} \mathrm{W}\right)$. Coll May 1956 and subm April 1975 by A T Lucas. Comment (ATL): mill appears to have been assoc with neighboring early church site.

\section{Carnsore series}

Samples from site at Saint Vogue's Church and Enclosure, Carnsore, Co Wexford (52 $\left.10^{\prime} \mathrm{N}, 6^{\circ} 22^{\prime} \mathrm{W}\right)$. Coll Aug 1975 and subm Nov 1975 by A Lynch, Dept Archaeol, Univ Coll, Cork.

\section{HAR-1380. CS/1}

$$
\begin{array}{r}
1290 \pm \mathbf{8 0} \\
\delta^{13} C=-25.3 \% 0
\end{array}
$$

Charcoal, combined Samples CS/1 and CS/2, from 3 adjacent postholes of similar diam and depth, beneath layer of carbonized wood and burnt soil. Postholes possibly held corner supports of rectangular wooden bldg. Comment (AL): agrees well with archaeol evidence of Early Christian occupation phase.

HAR-1382. CS/3

$$
\begin{array}{r}
\mathbf{1 3 9 0} \pm \mathbf{8 0} \\
\delta^{13} C=-25.5 \% \text { o }
\end{array}
$$

Charcoal from trench, $1 \mathrm{~m}$ depth, beneath layer of burnt soil in SE quad of Enclosure. Comment (AL): agrees with archaeol evidence suggesting Early Christian occupation phase.

\section{Manekweni series}

\section{Mozambique}

Seven samples taken to span bldg and occupation of stone-walled enclosure at Manekweni, Mozambique $\left(20^{\circ} 11^{\prime} 05^{\prime \prime} \mathrm{S}, 34^{\circ} 50^{\prime} 42^{\prime \prime} \mathrm{E}\right)$. Architectural style is of Zimbabwe of Later Iron age of Rhodesia with which site is contemporary and closely related culturally and economically (Garlake, 1976a,b). Samples coll and subm July 1975 by P S Garlake.

HAR-1240. MU/ED120

$$
\begin{array}{r}
\mathbf{7 7 0} \pm \mathbf{9 0} \\
\delta^{13} C=-25.8 \%
\end{array}
$$

Wood from midden beneath Zimbabwe-type solid clay dwelling. Earliest evidence of occupation at site. Comment: small sample yield in lab process. For replicate sample, see HAR-1285.

\section{HAR-1250. MUED 4872}

$$
\begin{array}{r}
\mathbf{3 4 0} \pm \mathbf{7 0} \\
\delta^{13} \mathrm{C}=-24.9 \%
\end{array}
$$

Wood from timber fabric of destroyed structure in upper level, late phase in site's occupation.

HAR-1252. MUE/0539

$$
\begin{array}{r}
\mathbf{5 9 0} \pm \mathbf{7 0} \\
\delta^{13} \mathrm{C}=-24.0 \%
\end{array}
$$

Wood from sand beneath midden (same midden as HAR-1253 and $-1254 \mathrm{qv})$. 
HAR-1253. MUEA 0507

Wood from lowest level of midden formed during occupation of stone-walled enclosure. Comment: some rootlet contamination evident.

HAR-1254. MUEA 0102

$\mathbf{6 0 0} \pm \mathbf{7 0}$
$\delta^{13} C=-25.9 \%$ 。

Wood from middle level of midden (same midden as HAR-1253). Comment (PSG): deposit is stratigraphically later than HAR-1253 qv.

HAR-1255. MUIA110

$780 \pm 80$

$\delta^{13} \mathrm{C}=-25.4 \%$

Wood from midden immediately beneath stone wall of enclosure and assoc with its erection. Comment (PSG): sample, with HAR-1240 and -1285 qv can be taken to date 1st occupation of site.

HAR-1285. MUED/120

$$
\begin{array}{r}
\mathbf{7 5 0} \pm \mathbf{1 0 0} \\
\delta^{1 s} C=-25.8 \%
\end{array}
$$

Replicate sample from residual $\mathrm{CO}_{2}$ from HAR-1240 qv. Comment: small sample size accounts for larger than normal error term.

II. GEOLOGIC SAMPLES

HAR-931. RHU

A. British Isles

$11,520 \pm 250$

$\delta^{13} C=+1.4 \%$ o

Marine shells from Rhu on $\mathrm{N}$ side of Clyde Estuary, Scotland $\left(56^{\circ}\right.$ $0^{\prime} 25^{\prime \prime} \mathrm{N}, 4^{\circ} 46^{\prime} 45^{\prime \prime} \mathrm{W}$, NGR: NS26448392). Shells are incorporated in glacially reworked estuarine silt. Shell fauna is typical of "Clyde Beds" of Devensian Late-Glacial age. Deposit incorporated in basal part of Loch Lomond Readvance moraine at Rhu in Gareloch and overlain by glaciofluvial sand and gravel deposited during Loch Lomond Readvance and beach gravel deposited during Flandrian Transgression. Coll Nov 1974 and subm Dec 1974 by J Rose, Dept Geog, Birkbeck Coll, Univ London. Comment (JR): date is in general accord with dates derived from other shells coll from "Clyde Beds" in region of Clyde Estuary.

\section{Finchampstead series}

Two samples of assoc peat and wood from Valley Bog, near Moorgreen Farm, Finchampstead, Berkshire, England $\left(51^{\circ} 21^{\prime} 10^{\prime \prime} \mathrm{N}, 0^{\circ} 50^{\prime}\right.$ 25" W, NGR: SU802625). Coll and subm Sept 1975 by D M Keith-Lucas, Dept Bot, Univ Reading.

\section{HAR-1314. DMKLFINI}

$$
\begin{array}{r}
\mathbf{7 0 0 0} \pm \mathbf{9 0} \\
\delta^{13} C=-29.9 \% 0
\end{array}
$$

Wood (alnus glutinosa) from depth in peat bog corresponding to Boreal, Pollen Zone VIB. Comment (DMK-L): date indicates wood is not contemporaneous with peat (HAR-1319 qv) with which it was assoc and probably represents roots of alder of Atlantic age (Pollen Zone VII a) penetrating surface of Boreal peat. 


\section{HAR-1319. DMKLFIN2}

$$
\begin{array}{r}
\mathbf{7 9 0 0} \pm \mathbf{1 1 0} \\
\delta^{13} \mathrm{C}=-28.6 \%
\end{array}
$$

Peat, coarse detritus gyttja contanmg abundant wood fragments (larger fragments removed before subm) including Alnus glutinosa, and attributable by pollen analysis to Boreal period (Pollen Zone VIb). Comment (DMK-L): date not inconsistent with that indicated by pollen analysis.

\section{B. Iran}

\section{Jask series}

Two samples from Jask, Iran $\left(25^{\circ} 39^{\prime} 10^{\prime \prime} \mathrm{N}, 57^{\circ} 49^{\prime} \mathrm{E}\right)$ subm as part of prog aimed at elucidating recent coastal deformation in S Iran, to see whether sequential dating following leaching would reveal contamination by younger carbon. Coll Nov 1974 and subm Feb 1975 by C VitaFinzi, Univ Coll, London.

\section{HAR-1097. IBR2}

Shell (Circe [Parmulophora] corrugata [Dillwyn, 1817]) from cemented shelly deposit ca $5.5 \mathrm{~m}$ above high water. Comment: given ca $30 \%$ leach.

\section{HAR-1115. IBR2}

$$
25,610 \pm 640
$$

$$
\delta^{13} C=+1.4 \%
$$

Same sample as HAR-1097. Comment: given ca $75 \%$ leach.

General Comment (CV-F): results point to some contamination as inner date is older; confirmed by X-ray diffraction. High age, thus, taken to be minimum for deposit (Vita-Finzi, 1975). Other ages being run on unaltered shell.

\section{HAR-1114. ILT2}

$$
\begin{array}{r}
110 \pm 90 \\
\delta^{13} C=-18.6 \%
\end{array}
$$

Charcoal, mixed with silt, taken at depth $0.55 \mathrm{~m}$ in sec $2.9 \mathrm{~m}$ deep exposed by wadi incision of Minab Alluvium, younger of 2 alluvial fills icl in W part of coastal Iranian Makran (Vita-Finzi, 1975). Sample coll at

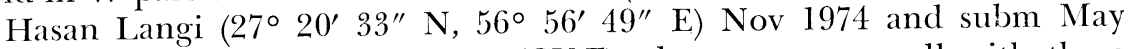
1975 by C Vita-Finzi. Comment (CV-F): date compares well with those obtained for analogous fill in $\mathrm{N}$ and central Iran and in Musandam Peninsula of Oman.

\section{Qatar}

\section{Qatar series}

Shell and charcoal samples coll in Nov and Dec 1973 by C Vita-Finzi, Univ Coll, London, during archacol and environmental study of Qatar (de Cardi, 1978). Subm by C Vita-Finzi, 1974. Shell ages not corrected for $\delta^{1: C}$. Values for shells are provided for information only. 
HAR-522. QB 23

$\delta^{13} C=+2.4 \%$

Unaltered shells (Circe callipyga Born, Trachycardium rubicundum [Reeve]) from fossil beach ca $4.5 \mathrm{~m}$ above high water at al-Wakrah $\left(25^{\circ}\right.$ $\left.10^{\prime} \mathrm{N}, 51^{\circ} 37^{\prime} \mathrm{E}\right)$.

\section{HAR-523. QB 19}

Unaltered shells (Asaphis deflorata [Linnaeus]) from fossil beach $1.7 \mathrm{~m}$ above high water $\mathrm{N}$ of Khor $\left(25^{\circ} 42^{\prime} \mathrm{N}, 51^{\circ} 32^{\prime} \mathrm{E}\right)$.

\section{HAR-524. QB 20 b}

$>\mathbf{3 5 , 0 0 0}$

$\delta^{13} C=+2.6 \%$

Unaltered shells ( $C$ callipyga, Pinctada cf margaritifera [Linnaeus]) from fossil beach ca $+6 \mathrm{~m}, 4.5 \mathrm{~km} \mathrm{NE}$ of Shaqrah $\left(24^{\circ} 51^{\prime} \mathrm{N}, 51^{\circ} 26^{\prime} \mathrm{E}\right)$.

HAR-525. QB 13

$$
5830 \pm 70
$$

$\delta^{13} \mathrm{C}=+3.0 \%$

Unaltered shells ( $P$ cf margaritifera) from beachrock $2 \mathrm{~m}$ above high water seawards of al-Wusail $\left(25^{\circ} 30^{\prime} \mathrm{N}, 51^{\circ} 30^{\prime} \mathrm{E}\right)$.

HAR-526. QB 17

$$
\begin{aligned}
& \mathbf{2 7}, \mathbf{1 0 0} \pm \mathbf{9 0 0} \\
& \delta^{13} \mathrm{C}=+2.1 \%
\end{aligned}
$$

Shells (cerithiids) from beachrock $5 \mathrm{~m}$ above high water NW of Dukhan $\left(25^{\circ} 26^{\prime} \mathrm{N}, 50^{\circ} 46^{\prime} \mathrm{E}\right)$. Shell aragonite almost wholly replaced by high-magnesium calcite.

\section{HAR-527. QB 4}

$$
>\mathbf{3 5 , 0 0 0}
$$$$
\delta^{13} C=+2.6 \%
$$

Beachrock containing shell fragments (A deflorata, Circe cf arabica) overlying beach gravels $4 \mathrm{~m}$ above high water on $\mathrm{E}$ coast of Ras Abaruk $\left(25^{\circ} 35^{\prime} \mathrm{N}, 50^{\circ} 51^{\prime} \mathrm{E}\right)$. Aragonite wholly replaced by high-magnesium calcite; calcitic matrix.

\section{HAR-528. QB 10}

$$
\begin{array}{r}
\mathbf{5 3 7 0} \pm \mathbf{8 0} \\
\delta^{13} \mathrm{C}=+7.2 \%
\end{array}
$$

Unaltered cerithiids cemented by aragonite $(<5 \%$ of sample $) 1.5 \mathrm{~m}$ above high water $\mathrm{N}$ of Bir Zekrit (25 $\left.36^{\prime} \mathrm{N}, 50^{\circ} 50^{\prime} \mathrm{E}\right)$.

\section{HAR-529. QB 21}

$$
\begin{aligned}
& \mathbf{2 1 , 9 5 0} \pm \mathbf{5 5 0} \\
& \delta^{13} C=+2.4 \%
\end{aligned}
$$

Shells (cerithiids and small pelecypod valves) with some replacement of aragonite by high-magnesium calcite from beach $5 \mathrm{~m}$ above high water $5 \mathrm{~km}$ N of Dukhan $\left(20^{\circ} 23^{\prime} \mathrm{N}, 50^{\circ} 45^{\prime} \mathrm{E}\right)$.

\section{HAR-638. AM 2}

$$
\begin{array}{r}
1850 \pm 90 \\
\delta^{13} C=-27.1 \%
\end{array}
$$

Charcoal from slightly disturbed hearth $5 \mathrm{~cm}$ below surface of basin fill at Bir Markhiyah $\left(25^{\circ} 03^{\prime} \mathrm{N}, 51^{\circ} 10^{\prime} \mathrm{E}\right)$. 
HAR-639. RA 3

Charcoal from slightly disturbed hearth 2 to $4 \mathrm{~cm}$ below surface of basin fill at Bir Abaruk (25 $\left.35^{\prime} \mathrm{N}, 50^{\circ} 51^{\prime} \mathrm{E}\right)$.

General Comment (GV-F): HAR-523, -525, and -528 indicate slight uplift of Qatar peninsula over last $5000 \mathrm{yr}$ (Vita-Finzi, 1978; 1979). Remaining dates, either explicitly or implicitly minima, do not conflict with this view but their main value is to demonstrate need for rigorous sample selection and pretreatment. Two charcoal ages support contention that phase of silt deposition affected inland basins of Qatar during historical period (Vita-Finzi, 1978).

REFERENCES

Allen, D, 1974, Brenig 48A Post-Medieval settlement: Denbighshire Hist Trans, v 23, p 43-49.

Bradley, R, Over, L, Startin, D W A, and Weng, R, 1975/6, The excavation of a Neolithic site at Cannon Hill, Maidenhead, Berkshire 1974-5: Berkshire Archaeol Jour, v 68, p 5-19.

Coles, J M (ed), 1978, Somerset Levels Papers 4: Univ Cambridge, Dept Archaeol. 1979, Somerset Levels Papers 5: Univ Cambridge, Dept Archaeol.

Coles, I M and Orme, B J, 1976, The Sweet Track, Railway site, in Somerset Levels Papers 2: Univ Cambridge, Dept Archaeol, p 34-65.

1979, The Sweet Track, Drove site: Somerset Levels Papers 5, p 43-64.

Coles, J M, Orme, B J, Hibbert, F A, and Wainwright, G J, 1975, Somerset Levels Papers 1: Univ Cambridge, Dept Archaeol.

1976, Somerset Levels Papers 2: Univ Cambridge, Dept Archaeol. 1977, Somerset Levels Papers 3: Univ Cambridge, Dept Archaeol.

Coombs, D G, 1976, Callis Wold round barrow, Humberside: Antiquity, v 50, no. 198,

p 130-131.
de Cardi, B (ed), 1978, Qatar Archaeological Report: Excavations 1973: Oxford, Oxford Univ Press.

Dix, B, 1975a, Excavations at Odell, Bedfordshire: an interim report: Bedfordshire Co Council, Spring, p 3-4.

1975 b, Excavations at Odell, Bedfordshire: A second interim report: Bedfordshire Co Council, Autumn, p 4-5.

1979, Excavations at Harrold Pit, Odell, 1974-78: A preliminary report: Bedfordshire Archaeol Jour, v 14, in press.

Donaldson, P, 1977, The excavation of a multiple round barrow at Barnack, Cambridgeshire 1974-1976: Antiquaries Jour, v 57, pt II, p 197-231.

Drury, P J, 1973, Little Waltham: Current Archaeol, v 36, p 10-13.

Fairless, K J and Coggins, D, 1974, Excavations at Forcegarth Pasture, Teesdale: Durham Co Local Hist Soc Bull 17, p 36-38. Durham, p 13

Garlake, P S, 1976a, Excavation of a zimbabwe in Mozambique: Antiquity, v 50, p 146-148.

P 146-148. $1976 \mathrm{~b}$, An investigation of Manekweni, Mozambique: Azania XI, p 25-47.

Green, C J S, 1974, Interim report on excavations at Poundbury, Dorchester 1973: Dorset Nat Hist \& Archaeol Soc Proc, v 95, p 97-100.

Guilbert, G C, 1975a, Planned hillfort interiors: Prehist Soc Proc, v 41, p 203-221.

- 1975b, Moel-y-Gaer, 1973: an area excavation on the defences: Antiquity, v 49, no. 194, p 109-117.

1976, Moel-y-Gaer (Rhosesmor) 1972-3 — an area excavation in the interior, in: Harding, D W, (ed) Hillforts: later prehistoric earthworks in Britain and Ireland, London, Academic Press.

Heighway, C M, 1976, Ancient Gloucester, the story of the Roman and medieval city: Gloucester City Mus.

Hill, C, Blagg, $\mathrm{T}$, and Millet, $M$, in press, The Roman riverside wall at Upper Thames Street, London, 1974-76: London and Middlesex Archaeol Soc, Spec Paper No. 3.

Hobley, B and Schofield, J, 1977, Excavations in the City of London. First interim rept, 1974-1975: Antiquaries Jour, v 57, pt 1, p 31-66. 
Hurst, H, 1972, Excavations at Gloucester 1968-71: Antiquaries Jour, v 52, p 58-62.

Jackson, D A, 1976, The excavation of Neolithic and Bronze age sites at Aldwincle, Northants. 1967-71: Northamptonshire Archaeol, v 11, p 12-71.

Lawson, A J, 1976, Excavations at Whey Curd Farm, Wighton: East Anglian Archacol, rept no. 2, Norfolk, p 65-99.

Lucas, A T, 1969, A horizontal mill at Knocknagranshy, County Limerick: North Munster Antiquarian Jour, v 12, p 12-22.

Lynch, F and Allen, D, 1975, Brenig Valley Excavations 1974 (interim report): Denbighshire Hist Soc Trans, v 24, p 13-37.

Lynch, F, Waddell, J, Allen, D, and Grealey, S, 1974, Brenig Valley excavations 1973: interim report. Denbighshire Hist Soc Trans, v 23, p 9-64.

Macpherson-Grant, N C, 1977, Bridge-by-Pass: archaeological sites: East Kent Archaeol, Occasional paper no. 1.

Morgan, R A, 1976, Tree-ring studies in the Somerset Levels: The Sweet Track, Somerset Levels Papers 2, p 66-78.

1979, Tree-ring studies in the Somerset Levels: floating oak tree-ring chronologies from the trackways and their radiocarbon dating: Somerset Levels Papers $5, \mathrm{p} 98-101$.

Otlet, R L, 1976, An assessment of laboratory errors in liquid scintillation methods of ${ }^{14} \mathrm{C}$ dating: Internatl radiocarbon conference, 9th, Proc, Univ California, June
20-26, 1976 (in press).

Otlet, R L and Warchal, R M, 1977, Liquid scintillation counting of low-level ${ }^{14} \mathrm{C}$ in: Crook, $\mathrm{M} \mathrm{A}$ and Johnson, P, (eds) Liquid scintillation counting 5: London, Heyden \& Son Ltd, p 210-217.

Rogerson, A, 1976, Excavations on Fuller's Hill, Great Yarmouth: East Anglian Archacol, Rept No. 2, Norfolk, p 131-245.

Schoficld, J and Miller, L, 1976, New Fresh Wharf: I The Roman Waterfront: The London Archaeologist, v 2, no. 15, p 390-395.

Shoesmith, R, in press, Saxon and Medieval Hereford: Mono.

Vita-Finzi, C, 1975, Quaternary deposits in the Iranian Makran: Geog Jour, v 141, p 415-420.

1978, Environmental history, in: de Cardi, B, (ed) 1978, Qatar Archaeological Report: Excavation 1973: Oxford, Oxford Univ Press, p 11-25.

1979, Rates of Holocene folding in the coastal Zagros near Bandar Abbas, Iran: Nature, v 278, p 632-634.

Wakeman, W F, 1872/3, Paper on some antiquities of oak in the possession of J G V Porter, Esq, of Bellisle, Lisbellaw, Co Fermanagh: Royal Soc Antiquaries of Ireland Jour, $v 12$, p 16-18

Ward, A H, 1975, A radio-carbon date for the Bronze age in South-West Wales: a preliminary note on the excavation of a composite mound on Pentre Farm, Pontardulais, West Glamorgan: The Carmarthenshire Antiquary, v 11, p 3-20. 1978, The excavation of a Bronze age composite mound and other feature: on Pentre Farm, Pontardulais, West Glamorgan: Archaeol Cambrensis, v 127, in press.

Williams, J, 1975, Northampton: Current Archaeol, v 46, p 340-348. 